\title{
Institutional Variables and Student's Employability Skills Development in Public Universities in Cross River and Akwa Ibom States, Nigeria
}

\author{
Mary Anike Sule ${ }^{1}$, Francisca Nonyelum Odigwe ${ }^{1}$, Ovat Egbe $\mathrm{Okpa}^{1}$, Emmanuel Sunday Essien ${ }^{1} \&$ \\ Mary Ibene Ushie ${ }^{1}$ \\ ${ }^{1}$ Department of Educational Management, University of Calabar, Nigeria \\ Correspondence: Emmanuel Sunday Essien, Department of Educational Management, University of Calabar, \\ Calabar, Nigeria. E-mail: emmanuelessien25@yahoo.com
}

\author{
Received: February 8, 2020 \\ Accepted: July 6, $2020 \quad$ Online Published: October 23, 2020 \\ doi:10.5539/ies.v13n11p33 \\ URL: https://doi.org/10.5539/ies.v13n11p33
}

\begin{abstract}
This study addresses institutional variables as determinants of employability skills acquisition among undergraduates in Cross River and Akwa Ibom States, Nigeria. Three research hypotheses were posed to guide the study. A descriptive survey research design was employed for the study. The population comprised of final year students in Faculty of Education at the University of Calabar numbered 904 and University of Uyo 939 respectively. Stratified random sampling technique was used to select data and a sample of 108 was drawn from University of Calabar and 112 drawn from the University of Uyo. A self-structured rating scale titled "Students' Employability Skills Acquisition Scale (SEASAS). Face and content validity of the instrument was done by supervisor and experts, Cronbach alpha reliability coefficient range were .73-.92. Hypotheses were analyzed using $\mathrm{t}$-test (population and independent $\mathrm{t}$-tests) and one-way analysis of variances (ANOVA), hypotheses were tested at 0.05 level of significance. The result of the study revealed among others: institutional variables on the levels of employability skills after their years in various programmes were not significantly low. Based on the findings, it was however recommended among others that; employability skills studies should be embedded in the university curriculum, university authority should make programmes of study more elaborate and rich in content to equip students with skills. Academic programmes in the universities irrespective of the school-age and terms of conditions should also be given basic priorities.
\end{abstract}

Keywords: institutional variables, student's employability skills, determinant, universities

\section{Introduction}

Unemployment is among the highly rated challenges among graduates globally, and as such, one wonders whether the level of skills acquired by graduates from various institutions does not match with the organisational demand for manpower skills. In an increased number of higher institutions in Nigeria, and the world market experience, so much concern has been expressed about the quality of Nigerian students. Graduates have been described variously as half-baked, ill-equipped, ill-train, ill-discipline, liability, lower standard, of poor quality and unemployable (Francis 2015) as cited in Francis (2015), a graduate is expected to acquire knowledge while in the university to give him an edge in the competitive society. Upon graduation from his programme, it is expected that the students must have gone through a standard procedure of training for the award of the degree certificate. Unemployment of graduates from Nigerian tertiary institutions has become a major national problem. National Bureau of Statistics (2015) unravels spontaneous rate of unemployment of Nigerian graduates. Despite the effort by Federal government to ensure the reduction of unskilled graduates by establishing various internship programmes for graduates, employers of labour still finds graduates lacking in different skills such as problems solving skill, self-management, teamwork, Information and Communication Technology(ICT) skills and innovation skills FRN (2019). Meanwhile, Universities was to remedy the level of unemployment rate in Nigeria by designing University programmes to reflect the organizational demands for skills.

Undergraduate programmes are at the centre of university education with the aim of training students in various disciplines and academic field of study to provide the needed manpower in various sectors of the economy. They are designed to produce standard and competitive graduates worldwide. University programmes aim at ensuring that students graduate with experience, ideas and potentials that will enable them to fit in a given organization and also fulfil their aspirations in their respective organization, relate productively with others in diverse view in 
achieving organizational set goals, impart meaningfully to the Nation within his /her environs within speculated periods. Akuegwu (2013) sees skills as the ability to solve societal problems. The goal of the university as prescribed by Federal Republic of Nigeria (2013) focuses on reducing skills shortage through the production of skilled manpower relevant to the needs of the labour market by making provision for graduate internship programmes. This is why universities are tailoring their programmes towards equipping students with skills, especially the ones that aid in securing jobs for themselves or employ others.

Students' employability skill means the exploration of knowledge and skills that are required by the labour market either for self-employment or the industrial sector. Effective management of academic programmes in the university leads to the production of graduates with employability skills. Employability skills denote characteristics like ICT ideas, self-management ideas, teamwork ideas, innovation ideas and skills, problem-solving attributes, time management attributes, decision-making attributes, critical thinking attributes, creative experience, organisational work experience, risk management experience, leadership attributes, analytical skills, descriptive skills, adaptive skills, events management skills that will build an individual a potential employee (Bridgstock, 2009). These skills and experiences are exactly connected to the requirement of the labour market and the compulsory adding of employability skills in higher institutions was put forward severally by Nigeria university commission. The high rate of unemployment as held by the National Bureau of Statistics (2019) shows that graduates lack the required employability skills for either self-employment or employment by the industrial sector.

The management of academic programmes is to plan and supervise the equipment of students with various employability skills and knowledge during the course of studies to fit into the labour markets or to be self-employed at graduation. The programmes designed by Nigeria Universities includes Regular programme, Direct Entry programme, Part-time (CES) Programme, Sandwich (holidays), and Postgraduate programme. These programmes provide avenues for developing skills as specified in the curriculum of the university. The programmes have various duration (years of study) and periods of the academic calendar (NUC, 2013). These programmes are expected to make students reason more importantly about the favourable time that may help them in building attributes like team spirit. National Universities Commission (2016) has it that the universities curricular do not see the building of knowledge and experiences in the process of being employed, but also to enhance the recipients' ability to solve fundamental societal problems. Being able to perform well like communication, team spirit and solving practical problems looks vital in building the study skills experience necessary for an academic breakthrough. Improving the available ideas, skills and building new attributes may create important help in achieving suitable employment outcome and render further examples for individual advancement needed by the employer.

Also, universities academic programmes specialise in teaching students the skills needed and bolster their efforts to thrive academically. The management of these academic programmes contributes to student's acquisition of these skills as well as individual support. Personal skills and experiences are necessary to job recruiters because they are seen as vital signs of what evidence it takes to be more successful in the organization or upon his plight. The work organisation is in a stage of continuous change or improvement. This shows why employer of labour still finds graduates lacking in some basic skills, particularly problem-solving skills, decision-making skills, self-management skill, risk management, innovation skills, adaptation skill, events management skills, and ability to prioritize tasks.

It is necessary to identify the fact that education can be an avenue to an end; it can also be a tool for getting employment and development of oneself through adequate provision and acquisition of core skills and ideas to flourish and paint lives more meaningful. Based on this background, the researcher intends to examine the extent undergraduates acquire employability skills in universities in terms of levels of employability skills, the programme of studies, and institutional difference and students' employability skills acquisition.

\subsection{Statement of the Problem}

In recent past, higher institutions have initiated various programmes aimed at strengthening the academic programmes with the hope that it will equip students with skills necessary for employment, entrepreneurship and job creation instead of being job seekers at their graduation. Sequel to the directives by the Federal Republic of Nigeria to all tertiary institutions to offer skill acquisition courses in various programmes to equip graduates with skills acquisition in the tertiary institution as required by employers of labour or for self-employment.

Despite federal government effort to reduce skill shortage and to improve employability skill among students, one wonders why the unemployment rate among graduates of the tertiary institution are increasing at a geometrical rate in Cross River and Akwa Ibom states in particular and Nigeria in general. The educational sector stakeholders, 
employers of labour, parents and the business sector find it difficult to determine why the skills acquired by graduates of the universities are still below acceptable employment level when measured by the huge investments in the university education. As a result of this backdrop, it becomes necessary to investigate the extent to which instructional variable influence the level of employability skills among undergraduate in Universities?

\subsection{Literature Review}

The rationale behind the expansion of higher education not only in Nigeria but elsewhere globally is to oversee the equipment of graduates in the competitive market about skills needed in knowledge-driven society and in stepping up the human capacity and job vacancies for all applicants and undergraduate for self-development. According to Wilton (2015) states that employability skills enable young school leavers and graduates to excel in their careers choice upon personal plight. Wilton (2015) highly ranked workers enable given organizations to meet the rate of rising and falling in requesting for new products and services of the workers in an organisation.

A few meanings of employability spotlights on the individual viewpoints, similar to understandings, osmosis of work information and accomplishments of people liable to commendation and look after business, and to advance in a given association and to create professions. In a similar vein, employability as an arrangement of achievement, absorption, and individual characters and attributes that assemble people more inclined to pick up work and be effective in their private issue.

The above definitions revealed how an individual can be employed. In commensuration to the above definitions, the researcher stressed that the graduates haven't possess the above-mentioned attributes should be successful in their career having possessed those vital skills aspects. Jonck and Van der Walt (2015) characterize employability as the ceaseless procedures of procuring, making of work utilizing the ideal utilization of possibilities. This implies appropriate manageability of business and works handle that assistance in keeping consistent abilities approach building. This simplifies that individual does not only acquire employment but also keep his/her skills in a continuous building process. Yorker and Knight (2004) characterize employability as an arrangement of aptitudes achievement, absorption of work knowledge and personal experience that build graduates to be more likely to be self-employed or be employed by others in an organisation and be succeeding in their chosen profession, to gain them, the organisation, their environs and the economy at large. In wider and inclusive content of the definition of employability, it exposes that the individual should enable to inculcates certain skills and attributes to be self-employed, and in gaining employment and succeeding in a personal career. Furthermore, the definition indicated that individual success with employability skills must benefit the individual at first, work organization, environs and the nation at large.

In agreement to Wilton (2011), he given strengths of the business undertaking and administration of graduates to the work showcase has developed imperatively

1) Government guiding principles or high-rank level 'skills 'in an organisation. This dimension is concerned with the organizational dynamics and the changing nature of work and employment.

2) Identifies with a part of asserting employability in light of aptitudes and individual abilities and adaptability procured through the workplace.

3) Employability being staged as a concern ability of the tertiary institution to equip graduates with those skills individual and organisational need.

The contains of employability is different measurements like the genuine capability of an individual, individual instructive capabilities gain through formal instructive exercises, hard abilities, and delicate aptitudes, including transferable fitness, interpersonal aptitudes and there are twofold noteworthy parts of employability, like the subject and transferable capacities. Transferable aptitudes insinuate certain individual limits of an individual secure from past contemplations, which can be taken from one employee in a past hierarchical part to another, used inside a given calling and at any period of his/her calling while subject capacities are more fundamental to one's calling.

\subsection{Programme of Study and Students Employability Skills}

Universities have different academic programmes designed to carter for all-round needs of both the employers of labour and students' career choice. These programmes range from National University Commission (NUC, 2013). These studies programmes are expected to be embedded with employability skills necessary to one's career choice upon venturing to the labour market or be self- employed. These programmes per-say, are directly offered by students under the auspices of the academic field of studies and then channelled to academic discipline. Resultantly, the developmental programme of study which sequentially and elaborately builds genes traits and discipline character, experience and skills in a competitive challenge to design a methodology towards addressing 
the existing phenomenon. It is towards this competitive contest that most universities now focus on addressing them. Nevertheless, building a university mission statement on graduate aspects becomes the simplest part towards ensuring that the teaching, curriculum and assessment thus, promote the building of the graduate's attributes in broad-based. But its' strictly different in sciences, where the students spent 5years which is sixty months and in terms of month, four hundred and twenty weeks in the science-related discipline.

In the areas of medicines, it takes eighty-four months which implies five hundred and eighty-eight weeks and yearly; it is seven years including internship programme. This helps to keep pace with global competition of other graduates from other universities. From this perspective, fresh graduate adapting to the new business environment will be dependent on the previous academic programme performance upon which they graduated from each and their respective universities and their different academic programme as well. According to them, those vital elements necessary to enable the graduate to live up to expectation is employability skills-experiences and attributes that are transferred on-the-go in university education. It is necessary to believe in work organisation that university dangers their tutors to equip students with their match ideas and skills to achieve a predetermine objectives in the workplace. This said skill should be imparted upon students' in pursuance of their regular academic programmes to help them excel upon venturing into the labour market. Absence of employability skills creates unemployable graduate in the labour environments and thereby imposed problems to the academic managers and depreciate the value of the universities which the graduate previously enrolled.

The level of skills acquired and years of studies spent in higher institution. He conducted a research study to know which factors influence the increase of skills acquisition by regular students in the first contact to the fifth contact, using bivariate correlations and regression analysis as statistical tools. In the researcher's' findings, the first contact mainly builds up students' skills and prepare them for the bigger and broader task ahead of them in the fifth contact, at this period, is all-ready prepare to get ready for graduation and during this time, proved to be encouraging. Some just went to school to acquire a certificate to gain promotion in their various places of work. He further stressed that some may attend school just to attain higher educational certificate for political positions and not interested in the acquisition of employability skills. Crandell and Smaldino (2000) observed in his finding on applicability of skills acquisition stressed that part-time students are less committed to studies because of their various engagements in the places of work. He further noted that these categories of students lack enthusiasm in studying school courses but rather concerned about the pending higher degree certificates.

Similarly, the findings regarding sandwich programmes and student's acquisition of employability skills falls in line with the views of Ajayi et al. (2010) reported that sandwich students who required effective and efficient performance on their place of works/assignments enrol in school to increase their productivity and skills to improve job performances. Such performances, to some extent, may solely rely greatly on intuition-knowledge, skills, and personal confidence to use and creative skills to know how best to execute tasks in a given job. However, there is the essence of student's building programmes and internship which focus on improving individuals' effectiveness at the work environment and for the higher task.

Sandwich programme of study will have equipped students with necessary skills if well-equipped with appropriate learning facilities, less production of man-power skills may be below an acceptable expected level. Most importantly, much graduate lack of job sustainable skills ideas and knowledge acquired through training from tertiary education, or any higher institution of high learning. The basic role of student's skills building, involved adequate standard of development of individual competence in individual career and personal awareness and development, impart an undergraduate level of potentials for further work upon graduation from the institution and also enhance in them the potentials to achieve their personal goals.

Other forms of employability skills acquisition and advancement imbibe students' with knowledge and skills as needed by them in other to qualify for jobs in the new changes and innovation society and recession. This kind of situation worth being in vogue with changes and innovation towards current developments in related responsibilities, work performance and standards, tools and equipment, or work ethics. Similarly, in a competitive world now, every organisation cannot reject the importance value in projecting the organizational co-existent. Hence, as a potential graduate, there should need to relate positively to communication skills at most. In commensuration the effort of the federal government to improved valued skills for students in some discipline when he pointed on the federal government (SIWES). Federal Government of Nigeria (2019) shows a strong commitment to supervising industrial Work Experience scheme SIWES to provide workplace experience for students in some disciplines at the undergraduate level. Only students in Engineering, business environment and some science courses are mandatorily required to undergo the six-month training which is funded by the Federal Government through industrial training fund. In synopsis, responding to the problem of finding and difficulties in securing placements at cognate establishments for students has severely limited the effectiveness of governments' 
good intentions. This programme excludes undergraduate students in the Arts. Humanities, Education and social sciences and postgraduate students are only exposed to traditional and specific theories of their degree courses. The reason behind this scenario is that the government decided to emphasize the low percentage of the minor group that consists of graduates to the negligence of other larger population of art, management, social sciences, and education.

In Nigeria and globally, universities or institutions are regarded as the citadel of learning, teaching pivotal research work and as well as community relation. They are also known as institutions of higher education which are meant for the transferring of knowledge and skills acquisitions in the certain academic field of studies to disciplines through classroom teaching and learning. Ayeni and Adelabu (2012) the level of enhancing learning foundation and environment for supportable quality affirmation rehearse in auxiliary schools in Ondo State, South-West, Nigeria utilizing an elucidating study outline, the review comprised of 60 principals and 540 instructors out in the open optional schools, three research questions and relating speculations were utilized to investigate the theories at 0.05 level of hugeness utilizing rate, mean score and Pearson Product Moment Correlation Coefficient examination. The review uncovered that educators view of value taking in the framework and environment ranges from 41 to $60.5 \%$, while the schools with a deficient quality range from 19 to $59 \%$. According to the researchers, this implies that learning environment contributes immensely to the institutions similarly, its' also contributes to the building and impartation of learning experiences and skills in graduates in universities at all level of learning. One of the major aspects that promote universities is a conducive learning environment. This is achieving through quality performance by the students and acquisition of experience in universities as one of the important aspect of enhancing quality institutional differences.

Education is a dual functional organisation which is basically for the development of individual and for national development. Hence, education without a fortified institution and quality personnel for teaching become a skeletal frame. Learning is an interaction between response and stimuli. A good institution is a true reflection of the good environment which reinforces the effort of the academic staff and learners by providing effective teachings, the teaching of research and community services to enhance a kind of learning that will aids undergraduate with employability skills. For instance, Ayeni and Adelabu (2012) posited that such stimulus is not only achieved as a result of learning interaction or thoughtful interaction but also by constant interaction with physical plants through proper maintenance of such facilities.

NUC ranking (2016) institutions are more likely to be lacking behind in Nigeria, this is because of the poor funding attitudes portrayed by the owners of the universities. This has in another way round caused low demands of the employee in their various organizations. This is subject to low skills imparted by the university tutors and poor learning attitudes from the learner's side. The management of the universities should have made possible outcome on learners irrespective of the low income and broken homes saddled with blames, to be responsible for half-bake graduate. Since the inception of institutions, graduates employability is a key and fundamental issue for higher education. Jonck and Van der Walt (2015) study on analysing graduate employability skills in South Africa, with a sample consisting of 250 private-sector workers and 253 public sector employees in South Africa pointed at interpersonal skills as a vital facet in achieving organizational set goals be it public or private sector. This indicates that there only existed slight differences between public and private sectors through generic skills of self-responsibility.

\subsection{Objectives of the Study}

The following are the objectives of this study:

1) To determine the level of employability skills among students public universities in Cross River and Akwa Ibom States, Nigeria.

2) To find out how the programme of study influence student employability skills development

3) To find how institutional differences differs from one university to another.

\subsection{Hypotheses}

Three correspondent research hypotheses were raised to give the study bearings:

1) Students' Level of Employability Skills acquisition in Universities is significantly low.

2) Programmes of studies do not significantly influence student's employability skills development in Universities.

3) There is no significant difference in the mean rating of institutions between Universities. 


\section{Methodology}

This study sought to examine institutional variables and students employability skills acquisition in universities in Cross River and Akwa Ibom States, Nigeria. This study process was map out to examine employability skills acquisition among undergraduates in the Universities. The study was identified to be under the categories of descriptive survey research design. The research design was seen suitable because it is used to find out situations, events, attitudes or opinions occurring in a population. It addresses issues of distribution of some phenomena in a population or among sub groups of population.

The study area for this study are Cross River and Akwa Ibom States, they are both located in the coastal Southern part in the federal republic of Nigeria, they are among the thirty six (36) States. There are two universities located in each of the state, one federally owned university in each state and one state owned university in each state, the emphasises of this study is on federally owned universities.

This study comprises of all the final year students in faculty of education in both University of Calabar and University of Uyo. The population was chosen because the researcher believes that they have spent years in receiving lectures and have good knowledge of skills acquisition imparts to them during the process of undergoing their various academic disciplines. There are 421, regular programme students, 150 part-time/CES students, 333 sandwich students making a total of 904 final year registered students in Faculty of Education, University of Calabar (2019)Teaching Practices Registration, Faculty of Education University of Calabar as at during research study investigation. While in University of Uyo, there are 386 Regular programme students, 210 part-time/CES students, 343 sandwich programme students which makes a total of 939 final year students in Faculty of Education University of Uyo. University of Calabar (2019). This gives a total population of 1843.

The researcher adopted stratified random sampling technique. The stratification was done on the basis of departments and as well as programme of study of the respondents. The researcher sample 13 departments in University of Calabar and 12 departments in University of Uyo. The names of departments and programmes of study in both universities were written in pieces of paper and folded into two containers to be drawn according to their departments and programme of study. Both universities were randomly selected based on departments and programme of studies respectively. 240 registered final year students drawn from the population. However, the study chooses 221 final year students from two universities, University of Calabar 108 and University of Uyo 113.

The research instrument that was used for this research was a modified 4-point researcher designed rating Scale title Students' Employability Skills Acquisition Scale (SESAS) to generate date for the study. Final year students were used to provide information. The instrument was sub-divided into two sections, Section A, and section B. Section A comprises of 3 demographic variables treated nominally such; employability skills level taught in the University, programme of studies and institution of study. In determining the level of employability skills, ICT only and self-management were group to be (low level) innovation, ICT, self-management and team work, ICT, self-management were group to be (moderate level) problem solving, ICT, self-management, innovation and team work were group to be (high level). While section B used rating scale to measured 30 questions made up of items such as: ICT skills, self-management skills, innovation skills, team work skills and problems solving skills. Final year students in Faculty of Education were inclined to elicit on Highly Versatile, Moderately Versatile, A Bit Versatile, Not Versatile, Highly skilled, Cope very well, manage to Cope, cope occasionally, cannot cope. The respondents are expected to identify their extent of agreement or disagreement with each item by ticking $(\sqrt{ })$ any of the options. The instrument was validated by experts in measurement and evaluation in university of Calabar, while trail test using Cronbach alpha reliability coefficient range from 0.73-0.92.this figure were considered reliable for use in conducting this research study. Collection of data was done by the researchers; this avenue gave room for $92 \%$ return rate. Analyses of data were done using; population t-test of single mean, One-Way Analysis of Variance (ANOVA) and Independent t-test.

\section{Scope and Limitations of the Study}

The subjects of this study were limited to institutional variables and undergraduate employability skills acquisition in universities in Cross River and Akwa Ibom States, Nigeria. Although there are three universities such as Arthur Jarvis University, Cross River University of Technology (CRUTCH), and University of Calabar (UNICAL) in the study area, the present study was delimited to two public Universities, which includes University of Calabar (UNICAL), and Cross River University of Technology. The institutional variables are level of acquisition of employability skills, programmes of studies and institutional differences. The limitation experienced by the researchers in the course of this study was the fact that the study relied on a self-rating questionnaire implying some respondents would have provided information to the questionnaire haphazardly. It also includes the inability of the researcher to determine the psychological state of the respondents at the time of administration of instrument 
in various universities during 2018/2019 academic session.

\section{Results}

Hypothesis one:

The null hypothesis states that levels of employability skills acquired by students in universities are significantly low. Population t-test statistics was adopted to test this hypothesis. The result of the analysis is presented in Table 2

Table 1. Population t-test analysis of undergraduate level of employability skills

Note. $\mathrm{P}<.05, \mathrm{df}=219$.

\begin{tabular}{cccccc}
\hline Variable & $\mathrm{N}$ & $\mathrm{X}$ & $\mathrm{SD}$ & $\mathrm{T}$ & value \\
\hline Level of Employability skills & 220 & 2.8727 & 1.20584 & 35.336 & 000 \\
\hline
\end{tabular}

Population t-test result in Table 1 shows an indication that there is a significant influence of student's level in the acquisition of employability skills at Universities. This is because the calculated t-value of 35.336 was significant with a p-value of .000 at .05 level of significance, with 219 degrees of freedom. Hence, the null hypothesis is therefore rejected and the conclusion reached is that student's levels of acquisition of employability skills at Universities are not significantly low.

Hypothesis two:

This hypothesis was stated in null form, this has it that there is no significant influence of programmes of study on undergraduate acquisition of employability skills in Universities.

Table 2. Summaries of data and One-Way Analysis of Variance (ANOVA) on the influence of programmes of study on student's acquisition of employability skills

\begin{tabular}{cccccc}
\hline Programmes of study & $\mathrm{N}$ & $\mathrm{X}$ & \multicolumn{2}{c}{ SD } \\
\hline Regularly programme & 54 & 66.9630 & 9.34650 \\
Part-time programme & 92 & & 71.5652 & 10.34281 \\
Sandwich programme & 74 & & 68.4324 & 7.84976 \\
\hline Total & 220 & & 69.3818 & 9.48056 \\
\hline Sources of variation & SS & df & MS & F & P \\
\hline Between groups & 821.230 & 2 & 410.615 & \multirow{2}{*}{4.724} & .010 \\
Within groups & 18862.697 & 217 & 86.925 & & \\
\hline Total & 19683.927 & 219 & & & \\
\hline
\end{tabular}

Note. $\mathrm{P}<.05, \mathrm{df}=219$, critical $\mathrm{F}=4.724$.

This hypothesis was stated in the null form, these have it that there is no significant influence of programmes of study on the undergraduate acquisition of employability skills in Universities. Programmes of study are the independent variable in this study and it was classified into three groups (regular programme, part-time programme and sandwich programme); while undergraduate' acquisition of employability skills stood as the dependent variable in this study. (ANOVA) was used to test this hypothesis. The result of the analysis is illustrated in Table 2 and 3.

The result in Table 2 shows an indication that the calculated Universities F-value of 4.724 is significant with a p-value of .010 at .05 level of significance with 2 and 217 degrees of freedom. This implies that the null hypothesis was rejected. This result, therefore, means that programmes of studies run by Universities have a significant influence on the undergraduate acquisition of employability skills in various universities.

To determine which of the programmes of study influences more on the undergraduate acquisition of employability skills, multiple comparisons were carried out and the result is illustrated in Table 3. 
Table 3. Fishers' Post Hoc tests on programmes of study and student's acquisition of employability skills

\begin{tabular}{ccccc}
\hline (I) Programme & (J) Programme & Mean Difference (I-J) & Std. Error & Sig \\
\hline \multirow{2}{*}{ Regular programme } & Part-time programme & $-4.60225^{*}$ & 1.59830 & .004 \\
& Sandwich Programme & -1.46947 & 1.66865 & .379 \\
\hline \multirow{2}{*}{ Part-time programme } & Regular programme & $4.60225^{*}$ & 1.59830 & .004 \\
& Sandwich Programme & $3.13278^{*}$ & 1.45585 & .033 \\
\hline \multirow{2}{*}{ Sandwich Programme } & Regular programme & 1.46947 & 1.66865 & .379 \\
& Part-time programme & $-3.13278^{*}$ & 1.45585 & .033 \\
\hline
\end{tabular}

In the above illustration from the table above, it can be seen clearly that part-time programme provides more influence on student's acquisition of employability skills than regular programme (mean difference $=4.60225, \mathrm{p}$ $<.05)$. In the same vein, sandwich programme has more influence on student's acquisition of employability skills than regular programme (mean difference $=1.46947, \mathrm{p}>.05$ ). This is because of the above mean respondent from students in sandwich and regular programmes. Similarly, sandwich programme has more influence on student's acquisition of employability skills than part-time programme (mean differences $=3.13278, p<.05$ ). However, the difference between sandwich programme and regular programme is not significant at .05 . It could be concluded that regular programme provide more influence on student's acquisition of employability skills among the three programmes of studies while the influence of part-time on student's acquisition of employability skills was the lowest. See Table 4 below.

Hypothesis 3:

There is no significant difference in the mean rating of institutions between the Universities

Table 4. Descriptive statistics and mean rating of institutional differences regarding acquisition of employability skills for students of University of Calabar and University of Uyo

\begin{tabular}{ccccc}
\hline Institutional differences & Universities & Mean & Std. Dev. & Decision \\
\hline \multirow{2}{*}{ Lecture delivery } & UNICAL & 3.4722 & .63332 & Highly adequate \\
& UNIUYO & 1.8124 & .66483 & Inadequate \\
\hline \multirow{2}{*}{ Academic environment } & UNICAL & 3.1481 & .75893 & Highly adequate \\
& UNIUYO & 2.5804 & 1.01908 & Moderate \\
\hline \multirow{2}{*}{ Academic performance } & UNICAL & 2.3889 & .96512 & Inadequate \\
& UNIUYO & 2.7500 & .86472 & Moderate \\
\hline \multirow{2}{*}{ Learning facilities } & UNICAL & 3.2593 & .78978 & Highly adequate \\
& UNIUYO & 1.5357 & .62858 & Inadequate \\
\hline \multirow{2}{*}{ Students/ teacher relations } & UNICAL & 2.3241 & 1.06630 & Inadequate \\
& UNIUYO & 1.9375 & .88309 & Inadequate \\
\hline \multirow{2}{*}{ Grand mean } & UNICAL & 2.9185 & .84269 & \\
& UNIUYO & 2.1232 & .81206 & \\
\hline
\end{tabular}

This hypothesis was stated in a null form which has it that there is no significant difference on institutional mean ratings between Universities in the development of employability skills. Institutional differences were the independent variable and undergraduate employability skills acquisition was the dependent variable for the study.

Data analysis in this hypothesis involved both descriptive and inferential tools. Means were used to analyzing the research question, while independent t-test analysis was also used for testing this hypothesis. A decision rule was made for the research question. A cut-off point of 2.50 was established as the mean result for the two research questions. A mean score range below 2.45 was regarded as inadequate, a mean score of $2.50-2.99$ was regarded as moderate while a mean score of 3.00 and above was regarded as highly adequate accordingly.

Table 5 presents the adequacy of institutional differences in terms of lecture delivery, academic environment, and academic performance, learning facilities as well as student/teacher relations at University of Calabar and University of Uyo respectively. From the table, UNICAL and UNIYO students had 2.9185 and 2.1232 grand means respectively. UNICAL mean score is more than the cut-off point of 2.50 while UNIUYO means the score is less than the cut-off point of 2.50 respectively. Following the decision rule earlier adopted, this indicates that 
students in UNICAL are of the opinion that the institutional differences in term of the earlier mentioned variables above are moderately adequate while that of their UNIUYO counterparts are inadequate to see Table 5 below.

Ho: This was done in null form thus there is no significant difference on institutional mean ratings between UNICAL and their counterpart (UNIUYO) in acquisition of employability skills.

Table 5. Summary of result and independent t-test analysis of the institutional differences on student's acquisition of employability skills between UNICAL and UNIUYO

\begin{tabular}{cccccc}
\hline Variables & $\mathrm{N}$ & Mean & Std. Dev. & $\mathrm{T}$ & p-value \\
\hline UNICAL & 108 & 2.9185 & .84269 & \multirow{2}{*}{6.45} & \multirow{2}{*}{0.000} \\
UNIUYO & 112 & 2.1232 & .81206 & & \\
\hline
\end{tabular}

Note. $\mathrm{P}<.05, \mathrm{df}=218$

To test this hypothesis, the mean rating of UNICAL and UNIUYO's institutional differences as regards the acquisition of employability skills was subjected to a t-test analysis for two independent samples and the results are presented in Table 5. The t-test evidence in Table 5 showed that there exists a significant difference in the opinion toward UNICAL and UNIUYO regarding students' acquisition of employability skills. This is because the calculated t-value of 6.45 is significant at .05 level of significance with 218 degrees of freedom. With this results evidence, the null hypothesis was rejected. Therefore this implies that there is no significant difference in institutional mean ratings between Universities in the development of employability skills. See Table 5 above.

\section{Discussion of Findings}

The result of the hypothesis one revealed that levels of employability skills acquired by students in universities are significantly low. This necessitated the rejection of the null hypothesis and accepts the alternate hypothesis.

The finding revealed that levels of employability skills acquired by students in universities are significantly low concerning ICT, self-management, innovative thinking, problem solving and teamwork. This by implication means that universities graduates are not well-equip as it should have been. The fall out of this is that since universities graduates are not well-equipped with necessary skills, it, therefore, follows that there may be the tendency of them not likely employed. This may lead to universities not achieving their desired goals of establishing the higher institution.

This study is supported by the research study of Wilton (2015) states that employability skills enable young school leavers and graduates to excel in their careers choice upon personal plight. In Wilton's (2015) study, highly ranked workers enable given organizations to meet the rate of rising and falling in requesting for new products and services of the workers in an organisation. Poor equipping of graduate has contributed greatly to graduate not getting employed and performing well in their place of work.

The result of the second findings also revealed that programmes of study significantly influence by Regular, regular programme is an organized NUC academic structure in which group of students are trained for a degree program. The sandwich is a non-NUC programme organized by the universities during their job vacation period. The part-time programme is an academic umbrella through which applicants who are working already obtained teaching and learning for the undergraduate acquisition of employability skills in Universities. This signifies that Regular, Sandwich and part-time programmes differ in their manners in which they acquire their skills. The result shows that the calculated F-value of 4.724 is significant with a p-value of .010 at .05 level of significance with 2 and 217 degrees of freedom. With this, the null hypothesis was ignored in favour of alternate hypothesis which implies that programme of study run by Universities has significant influence over students' acquisition of employable skills. It is, therefore, follows that universities in Cross River and the Akwa Ibom States have more skilful graduates in Regular and Sandwich Programmes.

Similarly, the findings of Crandell and Smaldino (2000) observed in his finding on applicability of skills acquisition stressed that part-time students are less committed to studies because of their various engagements in the places of work. He further noted that these categories of students lack enthusiasm in studying school courses but rather concerned about the pending higher degree certificates. However, the findings regarding sandwich programmes and student's acquisition of employability skills fall in line with the views of Haastrup (2010) who reported that sandwich students who required effective and efficient performance on their place of works/assignments enrol in school to increase their productivity and skills to improve job performances. Such performances, to some extent, may solely rely greatly on intuition-knowledge, skills, and personal confidence to 
use and creative skills to know how best to execute tasks in a given job. However, there is the essence of student's building programmes and internship which focus on improving individuals' effectiveness at the work environment and for the higher task.

The last hypothesis revealed a significant influence in the mean rating of institutional differences regarding student's acquisition of employability skills at UNICAL and UNIUYO in terms of learning infrastructure which includes the building, furniture, internet facilities, equipment, classroom, library or laboratory can contribute to quality education which can subsequently enhance and promote the acquisition of employability skills among students. This is because the result in Table 4 and 5 presents the adequacy of institutional differences in terms of lecture delivery, academic environment, and academic performance, learning facilities as well as student/teacher relations at University of Calabar and University of Uyo respectively. From the table, UNICAL and UNIYO students had 2.9185 and 2.1232 grand means respectively. UNICAL mean score is more than the cut-off point of 2.50 while UNIUYO means the score is less than the cut-off point of 2.50 . The reason for these findings stemmed from the facts that the University of Uyo belongs to the third generational universities and as such, is still under construction. This study is in line with that of Ayeni and Adelabu (2012), a serene school physical environment where good learning and good working plant are properly made available and managed, is an encouragement to effective teaching and learning. This examines the impact of institutional difference on skills acquisition of employability compares graduates from the institution of high learning programmes. This is so because the University of Calabar had long been inexistence, belonging to the second generation universities in Nigeria and had been before its counterpart.

\section{Conclusion}

University is the birthplace for skill breeding from the low skills which students were enrolled to a high level which student graduate out with various skills to solve various problems in the society. From the findings, it was revealed that institutional variables on the levels of employability skills after their years in various programmes were not significantly low, the second findings on the influence of programme of studies on students employability skills revealed that although part-time programmes post already equipped graduates since they are already on the job situation. But in general term, the findings posted that regular programme in universities in the study areas posts a high level of employability skills because of the time frame and the priority given to the students under this programme. As students from Sandwich and part-time programmes on attend lectures on their time frame. .The third findings show that institutional differences regarding student's acquisition of employability skills at UNICAL and UNIUYO in terms of learning infrastructure can contribute to quality education which can subsequently enhance and promote the acquisition of employability skills among students.

\section{Recommendations}

1) Attention should be given on the screening of the new intake in the various programme of studies in the universities, and same screening should be done during learning situation, all other respective skills that would enhance students' employability skills should be taken into cognisance.

2) Employability skills studies should be embedded in the university curriculum, university authority should make programmes of study more elaborate and rich in content to equip students with skills. Academic programmes in the universities irrespective of the school-age and terms of conditions should also be given basic priorities.

3) Proper funding of institution should be done by the sold agents such as state and the federal government should get involved in the proper funding of the universities to bridges collaboration between the instructors', students and universities set goals.

4) A similar study should be undertaken covering other variables and other universities in Nigeria using a different methodology. This is to extend the breadth of findings regarding the employability skills of undergraduate students.

\section{Acknowledgements}

The authors are grateful to undergraduate's students of both universities who participated in giving their honest response to these studies. The authors' profound gratitude goes to the various authorities whose works were cited in this study. The authors also appreciate their enthusiasm for the research assistants in gathering pertinent information.

\section{References}

Ajayi, I. A., Ekundayo, H. T., \& Osalusi, F. M. (2010). Learning environment and secondary school effectiveness 
in Nigeria. Studies on Home and Community Science, 4(3), 137-142. https://doi.org/10.1080/09737189.2010.11885312

Akuegwu, B. A. (2013). Appraisal of Nigerian University Students' possession of employability skills for global workplace in South-South Nigeria. Journal of Education Review, 6(3), 295-305.

Ayeni, A. J., \& Adelabu, M. A. (2012). Improving learning Infrastructure and environment for sustainable quality assurance practice in Ondo state, south-west, Nigeria. International Journal of Research Studies in Education, 1(1), 61-68. https://doi.org/10.5861/ijrse.2012.v1i1.20

Bridgstock, R. (2009). The graduate attributes we've overlooked; Enhancing graduate employability through career management skills. Higher Education Research \& Development, 28(1), 31-44. https://doi.org/10.1080/07294360802444347

Crandell C. C., \& Smaldino, J. J. (2000). Classroom Acoustics for Children with Normal Hearing and with Hearing Impairment. Language, Speech and Hearing in School, 362-370. https://doi.org/10.1044/0161-1461.3104.362

Faculty of Education Registration. (2019). Teaching practice registration. University of Calabar.

Faculty of Education Registration. (2019). Teaching practice registration. University of Uyo.

Federal Republic of Nigeria. (2013). Reducing skills Challenges in Nigeria.

Federal Republic of Nigeria. (2013). Reducing skills Shortage in Nigeria via Manpower production.

Jonck, P., \& Van der Walt, F. (2015). Understanding graduate employability skills in workplace environment. U.K. Bureau for employment. Labour press.

National Bureau of statistics. (2015). Percentages rate of unemployment in Nigeria.

National Bureau of statistics. (2019). The quarterly percent rate of unemployment in Nigeria.

National University Commission. (2013). NUC Curriculum.

Wilton, N. (2011). Do employability skills really matter in the UK graduate labour market? The case of business and management graduates. Work, employment and society, 25(1), 85-100. https://doi.org/10.1177/0950017010389244

Yorke, M. M., \& Knight, P. (2004). Embedding Employability into the curriculum. Learning and Employability series. LTSN Generic Centre.

\section{Copyrights}

Copyright for this article is retained by the author(s), with first publication rights granted to the journal.

This is an open-access article distributed under the terms and conditions of the Creative Commons Attribution license (http://creativecommons.org/licenses/by/4.0/). 